\title{
QUALITY MANAGEMENT IN CONSTRUCTION PROJECT: EMPIRICAL STUDY OF COVENANT UNIVERSITY SPORTS COMPLEX
}

\author{
SOLOMON OYEBISI ${ }^{1}$, ANTHONY EDE ${ }^{1}$, FESTUS OLUTOGE $^{2}$, BEN NGENE$^{1}$, \\ OLATOKUNBO OFUYATAN $^{1}$, and JOHN OLUWAFEMI ${ }^{1}$ \\ ${ }^{1}$ Dept of Civil Engineering, Covenant University, Ota, Nigeria \\ ${ }^{2}$ Dept of Civil Engineering, University of Ibadan, Ibadan, Nigeria
}

\begin{abstract}
The acceptable level of quality in construction projects has long been a problem. Significant resources are wasted on construction projects because of inefficient or nonexistent quality management procedures. Therefore, this study evaluates the quality management and the quality grading practices in the construction project with emphasis on the Covenant University Sports Complex. The quantitative research strategy and questionnaire survey were used as the main data collection instrument for soliciting information from the project participants in order to determine the best key for quality management practice. Moreover, an ultrasonic pulse velocity tester was engaged to assess and evaluate the conditions of concrete structural members. It was found out that management commitment to quality is the most key for effective quality management practices in the construction project. In addition, the ultrasonic pulse velocity (UPV) test carried out on the randomly selected structural members varied in the range $4.2 \mathrm{~km} / \mathrm{sec}$ to $4.6 \mathrm{~km} / \mathrm{sec}$. From this, it is inferred that the quality grading and homogeneity of concrete in the tested reinforced concrete columns, beams and slabs fall in the range of "good to excellent concrete". The findings would assist project participants in implementing an efficient quality grading and management while executing construction projects.
\end{abstract}

Keywords: Ultrasonic pulse velocity, Reinforced concrete, Questionnaire, Client, Consultant, Contractor.

\section{INTRODUCTION}

A construction project according to Ashokkumar (2014) goes through different phases such as conceptual planning, feasibility study, design, procurement, construction, acceptance, operation, and maintenance in its life span; and one of the important factors that determines the success of construction projects is quality. The effective management of construction project in all phases of its life cycle is linked to quality. Tan and Abdul-Rahman (2005) opined from the perspective of a construction firm that following the specified standard and maintaining the quality of construction works for the accomplishment of client's satisfaction resulting in the firm's long-term competitiveness and enduring business growth is referred to as "Quality Management in Construction Projects."

This predicates that faulty construction takes place if the project's quality is not in conformity to the specified standards and specifications. The wastages due to corrective action against shoddy jobs, lately discovered during construction and maintenance are found to be $6-15 \%$ and 
5\% of construction cost respectively (Akinci and Boukamp n.d. 2004, Fagbenle et al. 2009). In addition to this, Ogunde et al. (2017) stated that quality control, quality assurance, quality improvement, and quality standards are concepts encompassed and embedded in the term "quality management" in the construction firm.

\section{LITERATURE REVIEW}

\subsection{Quality Management Systems in Construction Industry}

Schlickman (2003) generally defines quality as "the degree to which a set of inherent characteristics fulfill requirements." This connotes that quality seems to be achieved in the construction firm whenever the client's needs and project participants are accomplished. Therefore, implementing the practice of quality management system in a construction company as a strategic management instrument requires the understanding of quality concepts in order to derive benefits from it. The principles of Quality Management Systems regarding quality include the establishment of policies and objectives by construction company to manage resources, the delegation of responsibilities, roles and authority to personnel, and the development of a company's structure among the personnel. The International Standard Organization has specifically incorporated the following eight quality management principles namely customer focus, leadership, involvement of people; process approach, system approach to management, continual improvement, factual approach to decision making, and mutually beneficial supplier relationships into its requirements (Schlickman 2003).

\subsection{Application of Quality Management in Construction Project}

The implementing concepts of quality management in construction project require the identification of quality standards (quality planning), the evaluation of overall project performance (quality assurance), and the monitoring of specific project results (quality control) (Chandrasena 2010). Quality assurance (QA) and quality control (QC) are importantly and mostly used in construction project. Tender documents, specifications, and working drawings are based on the quality control procedure in construction projects.

\section{METHODOLOGY}

\subsection{Principle of Approach Choice}

The study was posited in the positivist paradigm, which recognized and produced quantitative data that fit the survey approach, objectively gathered data as a small sample, and made an independent observation.

\subsection{Research Approach}

The study used the deductive research design as a result of substantial data and adopted the use of quantitative methods for analysis. The theory was tested by empirical observation.

\subsection{Research Strategy}

The study used quantitative strategy and questionnaires as the main data collection techniques.

\subsection{Data Collection Method}

Desk survey and field survey were adopted as approaches for collecting data in this study. 


\subsection{Data Collection Instruments}

\subsubsection{Questionnaire}

The researchers used a questionnaire adopted from (Schlickman 2003, Rumane 2011) and researchers' own experience in engineering field and construction management to achieve the study objectives. Generally, the questionnaire was developed by the researchers and appraised by specialists in academia and construction project management to gain a comprehensively statistical information from project engineers (client representatives), contractors, and consultants. The questionnaire was composed of two sections: Section one was focused on the respondents' profile such as education, position, and experience, while section two sought to determine whether the contractor is committed to quality implementation in their deliveries. The grading point was evaluated according to five-point Likert scale Level of Quality from excellent (5) to poor (1).

\subsubsection{Administration of questionnaire}

Pilot tests were subsequently conducted on the questionnaire for the contractor, the consultant, and the project engineers (client representatives) for the identification and the removal of potential obscurity to enhance the reliability and validity of the questionnaire. The questionnaires were directly administered on one-on-one basis.

\subsection{Data Analysis}

The data was analysed using MINITAB 17 software computer program. Reliability of internal consistencies was studied using Multivariate - Item Analysis while One-Way Analysis of Variance (ANOVA) was used to determine whether the means of two or more groups differ. Descriptive Analysis was used to compare relationships between variables.

\subsection{Reliability of Internal Consistency}

The data comprised 16 responses from experienced personnel within the construction company, with a $100 \%$ valid response rate. Cronbach's alpha value was used to determine the internal consistency of the construction of the section. If the value is closer to 1 , the internal consistency is higher. A value greater than 0.80 was considered to be good for significant consistency; value between 0.70 and .80 was acceptable for significant consistency while value lesser than 0.70 was considered poor (Sekaran and Bougie 2009). As shown in Table 1, the internal consistency of the measures adopted in this study was therefore considered to be acceptable and sufficiently reliable for the measurement of quality management in construction project.

Table 1 . The reliability of internal consistency.

\begin{tabular}{cccc}
\hline Section & Variable/Measure & No. of Question & Cronbach's alpha \\
\hline 2 & Quality implementation level in the firms & 20 & 0.8715 \\
\hline
\end{tabular}

\section{DATA ANALYSIS AND DISCUSSIONS}

\subsection{Respondents' Demographic Profile}

The test proportion (TP) according to Goodness-of-Fit Test (One variable) of the respondent details in each class from Table 2 was 0.25 , and P-value was $1.00(>\alpha=0.05)$ with no 
contribution to chi-square. This showed that respondent details had a $100 \%$ valid response rate and both observed values and expected values was equally fit in proportion.

Table 2. Respondents' demographic profile.

\begin{tabular}{lcccc} 
Respondent Information & Class & $\begin{array}{c}\text { Frequency } \\
(\mathbf{n = 1 6 )}\end{array}$ & $\begin{array}{c}\text { Percent } \\
(\mathbf{\%})\end{array}$ & $\begin{array}{c}\text { Cum. Percent } \\
(\mathbf{\%})\end{array}$ \\
\cline { 2 - 5 } Education Level & OND & 1 & 6.3 & 6.3 \\
& HND & 4 & 25.0 & 31.3 \\
& Bachelor's Degree & 9 & 56.3 & 87.6 \\
& Master's Degree & 2 & 12.5 & 100 \\
Education Background & PhD & 0 & 0 & 100 \\
& Architecture & 2 & 12.5 & 12.5 \\
& Civil Engineering & 9 & 56.3 & 68.7 \\
& Project & 3 & 18.8 & 87.5 \\
& Management & & & \\
Management Position & Quantity Surveying & 1 & 6.3 & 93.8 \\
& Other & 1 & 6.3 & 100 \\
& Top level & 6 & 37.5 & 37.5 \\
Experience & Middle level & 7 & 43.8 & 81.3 \\
& Low level & 3 & 18.8 & 100 \\
& 1-5 years & 2 & 12.5 & 12.5 \\
& 6-10 years & 3 & 18.8 & 31.3 \\
& 11-15 years & 6 & 37.5 & 68.8 \\
& 16 years \& above & 5 & 31.3 & 100 \\
\hline
\end{tabular}

Source: Field Survey 2018

\subsection{Quality Implementation Level}

The quality assurance implementation level of the construction firm was adopted from (Schlickman 2003) and evaluated in this part of the study. The respondents were given 20 questions of quality indices. The rank result of One-Way ANOVA is presented in Table 3.

The result of the level of quality implementation as presented in Table 3 indicated that the means of the quality indices are not significantly different. Also, the analysis of variance table statistics gave Adj SS, Adj MS, F-Value and P-Value as 10.31, 0.5426, 1.06 and 0.392 respectively. Since p-value (0.392) is larger than the $\alpha$-level selected $(\mathbf{0 . 0 5})$, it shows that the means are not significantly different. According to Table 3, the respondents ranked "Management Commitment to Quality" as the most important indices in achieving the quality management. This is in conformity with (Project Management Institute 2013) that keeping an accepted and consistent level of quality in the project and top management commitment to examine the needed experiment is very essential. "Client Satisfaction" was ranked $2^{\text {nd }}$. This confirms (Project Management Institute 2013)'s finding that the condition of an effective quality management system implementation is to ascertain that work is done according to specifications throughout the project life cycle and ensures that clients' satisfactions are met. Respondents' ranks of $4^{\text {th }}, 5^{\text {th }}, 6^{\text {th }} 7^{\text {th }}$ and $8^{\text {th }}$ also satisfied (Project Management Institute 2013). "Plan, Schedule and Assign Independent Personnel to Investigate Internal Quality Audits" was ranked as the least indices for implementing quality assurance by the respondents. 
Table 3. The company quality implementation Level $(\mathrm{N}=16)$.

\begin{tabular}{|c|c|c|c|c|c|}
\hline $\mathbf{S} / \mathbf{N}$ & $\begin{array}{c}\text { Quality Indices } \\
\end{array}$ & Mean & StDev & $95 \% \mathrm{CI}$ & Rank \\
\hline Q1 & $\begin{array}{l}\text { Evaluate, select and appropriately exercise control over the } \\
\text { capabilities for quality delivery by subcontractors }\end{array}$ & 4.500 & 0.632 & $(4.148,4.852)$ & 3 \\
\hline Q2 & Control of quality records & 4.375 & 0.500 & $(4.023,4.727)$ & 5 \\
\hline Q3 & $\begin{array}{l}\text { Verification control, storage, and maintenance of customer- } \\
\text { supplied product }\end{array}$ & 4.188 & 0.655 & $(3.836,4.539)$ & 8 \\
\hline Q4 & $\begin{array}{l}\text { Adherence to certified quality specifications such as the } \\
\text { Nigeria FMW\&H, Revised 2007; ISO } 9000\end{array}$ & 4.500 & 0.673 & $(4.148,4.852)$ & 3 \\
\hline Q5 & $\begin{array}{c}\text { Plan design activities by identifying, reviewing, verifying, } \\
\text { and validating design input }\end{array}$ & 4.313 & 0.704 & $(3.961,4.664)$ & 6 \\
\hline Q6 & $\begin{array}{l}\text { Inspection control, measuring and testing of equipment prior } \\
\text { to use and after use }\end{array}$ & 4.375 & 0.500 & $(4.023,4.727)$ & 5 \\
\hline Q7 & $\begin{array}{c}\text { Review, approve and control purchasing documents prior to } \\
\text { release }\end{array}$ & 4.250 & 0.856 & $(3.898,4.602)$ & 7 \\
\hline Q8 & Management commitment to quality & 4.625 & 0.500 & $(4.273,4.977)$ & 1 \\
\hline Q9 & Training for team members on quality & 4.438 & 0.727 & $(4.086,4.789)$ & 4 \\
\hline Q10 & $\begin{array}{l}\text { Review variation order prior to acceptance and transmit } \\
\text { corrected requirements to required functions }\end{array}$ & 4.000 & 1.155 & $(3.648,4.352)$ & 11 \\
\hline Q11 & $\begin{array}{l}\text { Verification of subcontracted work by the client } \\
\text { representative is allowed at the premises where specified in } \\
\text { contract document }\end{array}$ & 4.500 & 0.673 & $(4.148,4.852)$ & 3 \\
\hline Q12 & $\begin{array}{l}\text { Conduct receiving inspection and testing of incoming } \\
\text { materials and components in accordance with quality plan }\end{array}$ & 4.438 & 0.727 & $(4.086,4.789)$ & 4 \\
\hline Q13 & Corrective and preventive action & 4.313 & 0.704 & $(3.961,4.664)$ & 6 \\
\hline Q14 & Client satisfaction & 4.563 & 0.629 & $(4.211,4.914)$ & 2 \\
\hline Q15 & Handling, storage, preservation and delivery & 4.125 & 0.719 & $(3.773,4.477)$ & 9 \\
\hline Q16 & $\begin{array}{l}\text { Plan, schedule and assign independent personnel to } \\
\text { investigate internal quality audits }\end{array}$ & 4.000 & 1.033 & $(3.648,4.352)$ & 11 \\
\hline Q17 & $\begin{array}{l}\text { Conformity or nonconformity of work on the basis of } \\
\text { inspection and performance }\end{array}$ & 4.375 & 0.500 & $(4.023,4.727)$ & 5 \\
\hline Q18 & $\begin{array}{c}\text { Definition, establishment and documentation of quality } \\
\text { planning on a project or contract, and also preparation of a } \\
\text { quality plan }\end{array}$ & 4.500 & 0.673 & $(4.148,4.852)$ & 3 \\
\hline Q19 & $\begin{array}{l}\text { Identify, implement and control the application of statistical } \\
\text { techniques in quality control }\end{array}$ & 4.375 & 0.500 & $(4.023,4.727)$ & 5 \\
\hline Q20 & $\begin{array}{l}\text { Verification of servicing according to the required } \\
\text { specifications }\end{array}$ & 4.063 & 0.929 & $(3.711,4.414)$ & 10 \\
\hline
\end{tabular}

Source: Field Survey 2018

Table 4. The result of the UPVT.

\begin{tabular}{lcccc}
\hline Wing & RC Member & $\begin{array}{c}\text { Pulse Velocity by Cross } \\
\text { Probing }(\mathbf{P V C P})(\mathbf{K m} / \mathbf{s e c})\end{array}$ & $\begin{array}{c}\text { Average PVCP } \\
(\mathbf{K m} / \mathbf{s e c})\end{array}$ & $\begin{array}{c}\text { Concrete Quality Grading } \\
\text { IS: 13311-1 (1992) }\end{array}$ \\
\cline { 3 - 5 } 1 & Column & $4.5,4.8,3.9,4.4,4.4,4.5$ & 4.4 & Good \\
& Beam & $4.8,4.6,4.9,3.9,4.6,4.6$ & 4.6 & Excellent \\
& Slab & $4.0,4.7,3.8,4.5,4.5,4.0$ & 4.3 & Good \\
2 & Column & $4.6,4.5,4.6,4.7,4.6,4.5$ & 4.6 & Excellent \\
& Beam & $3.9,4.4,4.6,4.5,4.2,4.0$ & 4.3 & Good \\
& Slab & $3.9,4.5,4.2,4.4,4.3,3.8$ & 4.2 & Good \\
\hline
\end{tabular}

Source: Empirical Study 2018

\subsection{Non-Destructive Testing on the Structural Members}


An Ultrasonic Pulse Velocity Test (UPVT) was carried out at 28 days curing on RC columns, beams and slabs using an Ultra Pulse Analyzer (58-E4800 UPV tester) at randomly selected members in both wings. The experimental test on quality grading and homogeneity of concrete at randomly selected structural members varied from $4.2 \mathrm{~km} / \mathrm{sec}$ to $4.6 \mathrm{~km} / \mathrm{sec}$. The results (Table 4) showed that condition of concrete structures fall in the range of "Good to Excellent Concrete".

\section{CONCLUSIONS, LIMITATIONS, AND RECOMMENDATIONS}

Quality practices and client's needs and satisfaction were discovered as the key quality management techniques. Moreover, UPV test proved the concrete as good and excellent in term of quality grading. However, the study was limited to a certain geopolitical, cultural, and societal zone. Work commitment and pressure did not permit some respondents to have enough time to respond to the questionnaires, but the researchers always contacted and worked with them on site. Thus, the study recommended the quality management techniques in the execution of projects by construction engineers to build a safer society. Also, control and regulatory bodies in the construction environment should institute an award scheme for the best firm which strictly adheres to quality practices as a way of motivating them to use quality management techniques.

\section{Acknowledgments}

The authors appreciate the management of Covenant University for her financial support and the physical planning development for her technical support in course of the study.

\section{References}

Akinci, B., and Boukamp, F., Towards Automated Defect Detection: Object-Oriented Modeling of Construction Specifications, Carnegie Mellon University, Pittsburgh, USA, 1-12, 2004.

Ashokkumar, D., Study of Quality Management in Construction Industry, International Journal of Innovative Research in Science Engineering and Technology, 3(1), 36-43, 2014.

Chandrasena, G. L., Importance of Quality Assurance in the Building Construction Industry of Sri Lanka, National Building Research Organization, Sri Lanka, 2010.

Fagbenle, O. I., Olabosipo, I., and Owolabi, J. D., Developing a Realistic Budget for Construction Projects: Lessons from Nigeria, International Review of Business and Social Sciences, 1(3), 17-23, 2009.

IS: 13311-1, Method of Non-Destructive Testing of Concrete, Part 1: Ultrasonic Pulse Velocity (Ced 2: Cement and Concrete), Bureau of Indian Standards, New Delhi, 1992.

Ogunde, A. O., Olaolu, O., Afolabi, A., Owolabi, J., and Ojelabi, R., Challenges Confronting Construction Project Management System for Sustainable Construction in Developing Countries: Professionals Perspectives (A Case Study of Nigeria), Journal of Building Performance, 8(1), 1-11, 2017.

Project Management Institute, A Guide to the Project Management Body of Knowledge (5th Ed.), Project Management Institute Inc., Newtown Square, Pennsylvania, USA, 2013.

Rumane, A. R., Quality Management in Construction Projects, Boca Raton, FL: CRC Press, 2011.

Schlickman, J., ISO 9001:2000, Quality Management System Design, Artech House, London, Boston, 2003.

Sekaran, U., and Bougie, R., Research Methods for Business: A Skill-Building Approach (5th ed.), Wiley, Chi Chester-UK, 2009.

Tan, C. K., and Abdul-Rahman, H., Preliminary Research into Overcoming Implementation Problems in Construction Projects, 15-18, Micra Conference, Faculty of the Built Environment, University Malaya, 2005. 